\title{
MAR site suitability mapping for arid-semiarid regions by remote data and combined approach: A case study from Balochistan, Pakistan
}

\section{Mappatura dell'idoneità per l'utilizzo di tecniche MAR in regioni aride e semi-aride mediante l'utilizzo di remote sensing e di un approccio combinato: il caso di studio del Balochistan, Pakistan}

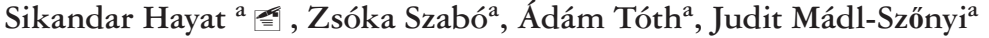 \\ ${ }^{a}$ ELTE Eötvös Loránd University, Institute of Geography and Earth Sciences, Department of Geology, József and Erzsébet Tóth Endowed \\ Hydrogeology Chair, Budapest, Hungary - email: sikandarhayat832@gmail.com
}

\author{
ARTICLE INFO \\ Ricevuto/Received: 09 March 2021 \\ Accettato/Accepted: 22 September 2021 \\ Pubblicato online/Published online: \\ 30 September 2021 \\ Handling Editor: \\ Giovanna De Filippis
}

\section{Citation:}

Hayat S, Szabó Z, Tóth A, Mádl-Szőnyi J (2021) MAR Site Suitability Mapping for Arid-Semiarid Regions by Remote Data and Combined Approach: A Case Study from Balochistan, Pakistan. Acque Sotterranee - Italian Journal of Groundwater, 10(3), 17 - 28

https://doi.org/10.7343/as-2021-526

Correspondence to:

Sikandar Hayat

sikandarhayat832@gmail.com
Keywords: Managed Aquifer Recharge (MAR), suitability mapping, GIS, Multi-Criteria Decision Analysis, groundwater resource management.

Parole chiave: Managed Aquifer Recharge (MAR), mappa di idoneità, GIS, Multi-Criteria Decision Analysis, gestione delle risorse idriche sotterranee.

Copyright: (C) 2021 by the authors Licensee Associazione Acque Sotterranee. This is an open access article under the CC BY-NC-ND license: http://creativecommons.org/licenses/bync-nd/4.0/

\section{Riassunto}

I cambiamenti climatici, il rapido aumento della popolazione e la cattiva gestione delle risorse idriche hanno portato ad un peggioramento della qualità e della disponibilità di acque sotterranee in tutto il mondo. Il Balochistan, la provincia più grande e più secca del Pakistan, si trova nella parte sud-occidentale del Paese. In questa regione, il calo della disponibilità delle risorse idriche sotterranee, la subsidenza e l'erosione del suolo sono problematiche molto importanti. Il rapido aumento della popolazione, l'innalzamento del livello del mare, l'aumento della temperatura, il calo delle precipitazioni medie annue e il verificarsi di precipitazioni intense e di breve durata con tassi di infiltrazione ridotti stanno ulteriormente aggravando la situazione. La ricarica controllata delle falde (Managed Aquifer Recharge - MAR) è considerata una soluzione per ridurre lo stress sulle risorse idriche sotterranee e favorire la resilienza ai cambiamenti climatici. La creazione di mappe di idoneità per l'utilizzo di tecniche MAR può rappresentare un importante passo verso la gestione sostenibile delle acque sotterranee. In questo studio viene presentata la prima mappa di idoneità per l'utilizzo di tecniche MAR nella Valle di Quetta, la città più densamente popolata del Balochistan, e per bacini costieri di Poralai e Hingol, dove l'intrusione salina rappresenta un grave problema. Per produrre tale mappa è stata utilizzata la piattaforma online INOWAS per selezionare le tecniche MAR più adatte. Successivamente sono stati identificati i sei principali fattori di influenza, tra cui la geologia, la pendenza, la copertura del suolo, le precipitazioni, la densità di drenaggio e l'uso del suolo. L'influenza di ciascun fattore è stata valutata e ponderata utilizzando strumenti GIS e il metodo Multi Influencing Factor (MIF). Tutti i fattori sono stati integrati in base al loro peso utilizzando lo strumento 'Weighted Overlay Analysis' e la Multi-Criteria Decision Analysis (GIS-MCDA) in ArcGIS per produrre la mappa di idoneità finale. La mappa di idoneità suddivide l'area di studio in classi di idoneità elevata, moderata, bassa e molto bassa. I risultati mostrano che l'80\% del bacino del Poralai, il 10\% del bacino di Hingol e meno del 5\% della Valle di Quetta ricadono nella zona di idoneità elevata, specialmente in corrispondenza di trincee, fossati, solchi e dighe. Questa mappa di idoneità può rappresentare una guida e uno strumento di screening per focalizzare studi sito-specifici in aree adatte all'implementazione di tecniche MAR. Nella fase successiva, uno studio localizzato sull'origine, sulla qualità e sull'uso finale dell'acqua può servire a sviluppare delle strutture MAR specifiche in base alle condizioni e alle esigenze locali. Il metodo utilizzato è applicabile a ulteriori studi di idoneità per altre regioni aride e semi-aride.

Abstract
Climate change, along with the rapid increase in population and mismanagement of water resources, resulted in a decline in the quality and quantity of groundwater worldwide. Balochistan, the largest and driest province of Pakistan, is located in the south western part of the country. This region is suffering from the declining water table, land subsidence, and intense soil erosion. Rapidly increasing population, sea level rise, increasing temperature, declining average annual precipitation, and short-duration intense rainfalls with reduced percolation rates are further aggravating the situation. Managed Aquifer Recharge (MAR) is considered as a solution to reduce the stress on groundwater resources and achieve resilience to climate change. Creating a MAR suitability map may be one of the steps to be taken to reach sustainable groundwater management. This study produced the first MAR suitability map of the Quetta Valley, the most densely populated city of Balochistan, and Poralai and Hingol coastal basins suffering from seawater intrusion. To construct the MAR suitability map, the online INOWAS platform was first used to narrow down the suitable MAR options. Then, the six influencing factors including geology, slope, land-cover, precipitation, drainage density, and soil were identified, and the raster map of each factor was scored and weighted using GIS tools and the Multi Influencing Factor (MIF) method. All the factors were integrated according to their weight by using the 'Weighted Overlay Analysis' tool and the Multi-Criteria Decision Analysis (GIS-MCDA) in ArcGIS to produce the final MAR suitability map. The suitability map divided the study area into high, moderate, low, and very low suitability classes. The results depict that $80 \%$ of Poralai Basin, $10 \%$ of Hingol Basin and less than $5 \%$ of Quetta Valley falls in the high MAR suitability zone especially for trenches, ditches, furrows, and leaky dams. The first MAR suitability map for the basins of Balochistan can serve as the guidance and screening tool to focus site specific studies for highly suitable areas for MAR implementation. In the following phase of the study, an analysis of source, quality, and final use of water can serve to design and develop the specific MAR structures according to local conditions and needs. The displayed method is applicable to further MAR suitability studies for other arid-semiarid regions. 


\section{Inroduction}

Groundwater is considered a dependable and important source of freshwater in all climatic zones (Todd and Mays 2004; Aeschbach Hertig and Gleeson 2012). The rapid global increase in the number of pumping wells in the last 50 years resulted in the green revolution. Agricultural yield increased because of the development of advanced agricultural techniques. The technical evolution enhanced the food supply, and fulfilled the industrial and municipal needs of the burgeoning population (Aeschbach Hertig and Gleeson 2012; Van Der Gun 2012; Giordano 2007). On the other hand, it also catalyzed groundwater decline and caused a plethora of problems including, but not limited to 1) negative effects on the ecosystems due to reduced groundwater discharge into springs, streams, and wetlands (Sophocleous 2000), 2) land subsidence, resulting in infrastructure damage (Giordano 2009), 3) increased pumping cost (Fishman et al. 2011), and 4) seawater intrusion which results in salinization of freshwater aquifers (Foster and Chilton 2003).

One solution to the problem of deteriorating water table is recharging aquifers using excess water during wet periods. The increased storage can then be used during the dry season (Dillon et al. 2010; Maliva and Missimer 2012; Arshad et al. 2014; Dillon et al. 2019). This technique is called Managed Aquifer Recharge (MAR), defined as "intentional recharge of groundwater to aquifers for subsequent recovery or environmental benefits" (Dillon et al. 2019). MAR methodologies include spreading methods, in-channel modifications, induced bank filtration, borehole recharge, and rainwater harvesting (Bouwer 2002). Along with MAR implementation, reduction in pumping, and promotion of water-effective agricultural practices are also crucial. The proper management of groundwater and implementation of MAR techniques can help mitigate the effects of climate change, e.g. by reducing evaporation, capturing run-off, reducing seawater intrusion, reducing the pumping cost, mitigating floods, etc. (Escalante et al. 2019).

The first step towards MAR implementation is the selection of an appropriate site. While choosing a suitable site, the major factors to be considered are mostly intrinsic such as topography, hydrogeology, land use, and soil type (Sallwey et al. 2019; Shankar and Mohan 2005; Saraf and Choudhury 1998). Criteria such as availability, consumption and quality of water can be integrated into the detailed study of sites with specific goals (Bonilla Valverde et al. 2016), e.g. agricultural use, domestic use, industrial use etc. Often, the unavailability of data is also a hurdle, as usually the data on the chemical quality of water is rarely available. MAR suitability studies are available across the globe, e.g. in India (Raviraj et al. 2017), Australia (Hostetler 2007), Brazil (Shubo et al. 2020), Spain (Escalante et al. 2014), United States of America (Russo et al. 2015), Jordan (Alraggad et al. 2010), Portugal (Rahman et al. 2012), and Tunisia (Chenini and Mammou 2010).

Remotely sensed data coupled with the advancement of Geographic Information System (GIS) tools have been playing a huge role in improving water resources research and management (Melesse et al. 2007; Rahman et al. 2012; Magesh et al. 2012; Bonilla et al. 2016). The conjunctive use of Multi-Criteria Decision Analysis (MCDA) and GIS commonly known as GIS-MCDA proved to be efficient for MAR site suitability mapping (Rahman et al. 2012). MCDA is defined as a combination of procedures to design, and evaluate alternative decisions (Malczewski 2006). GIS-MCDA is used to find the best possible solution for a spatial problem by logically analyzing and comparing different criteria with the specified value and geographical location (Ozturk et al. 2011). The advantage of the use of GIS-MCDA in combination with traditional field investigation and statistical methods consists in the increasing availability of surface and subsurface remote sensing data (Sallwey et al. 2019). This can be especially useful for MAR suitability mapping of those areas that are inaccessible due to security issues and lack of infrastructure.

The present study focuses on two goals. Firstly, proposing an innovative approach for the evaluation of MAR suitability based on remote data for arid-semiarid regions. Secondly, to display a comprehensive MAR suitability map of Quetta Valley, Poralai Basin and Hingol Basin of Balochistan, Pakistan based on the proposed approach.

\section{Study Area}

Balochistan (Fig. 1) is the largest province of Pakistan $\left(347,200 \mathrm{~km}^{2}\right)$, with an arid to semiarid climate, low precipitation (about $100 \mathrm{~mm} / \mathrm{year}$ ), and non-perennial surface water which makes groundwater the primary source for domestic and agricultural water use. The population of Balochistan increased rapidly between 1998 and 2017 (last census) by $90 \%$ and the current population (as of 2017) is 12.34 million (Ashraf and Sheikh 2017; Sagintayev et al. 2012). Droughts, unsustainable exploitation of groundwater, deforestation, and migration from neighbouring Afghanistan resulted in a rapid decline in the water table $(5 \mathrm{~m} /$ year in some areas). This caused deterioration in quantity and quality of groundwater along with triggering land subsidence (Ahmad et al. 2017; Sagintayev et al. 2012). The long periods of droughts are usually followed by flash floods resulting in huge damage to human life and property (Sagintayev et al. 2011). The seawater intrusion problem is intensifying in the coastal areas (Majeed and Qureshi 2000). The severe drought years (1998-2000) forced two million people to migrate from the area (Red Cross 2005). Coupled with natural disasters, the insufficient use of natural resources - water, rangeland, soil, forests and biodiversity - resulted in an increase in poverty and a decrease in quality of life. This serious situation led to reveal the significance of water preservation in the area with the involvement of MAR methods. Ashraf and Sheikh (2017) reviewed the MAR practices in Balochistan. According to them, to solve the worsening groundwater problems in Balochistan, 300 delay action dams were constructed in the 90 s to harvest run-off. The denuded catchment area and intense rainfall resulted in rapid sediment erosion and the dams silted up soon. They are no longer serving their purpose of recharging the aquifers but just reduced to evaporation ponds. 

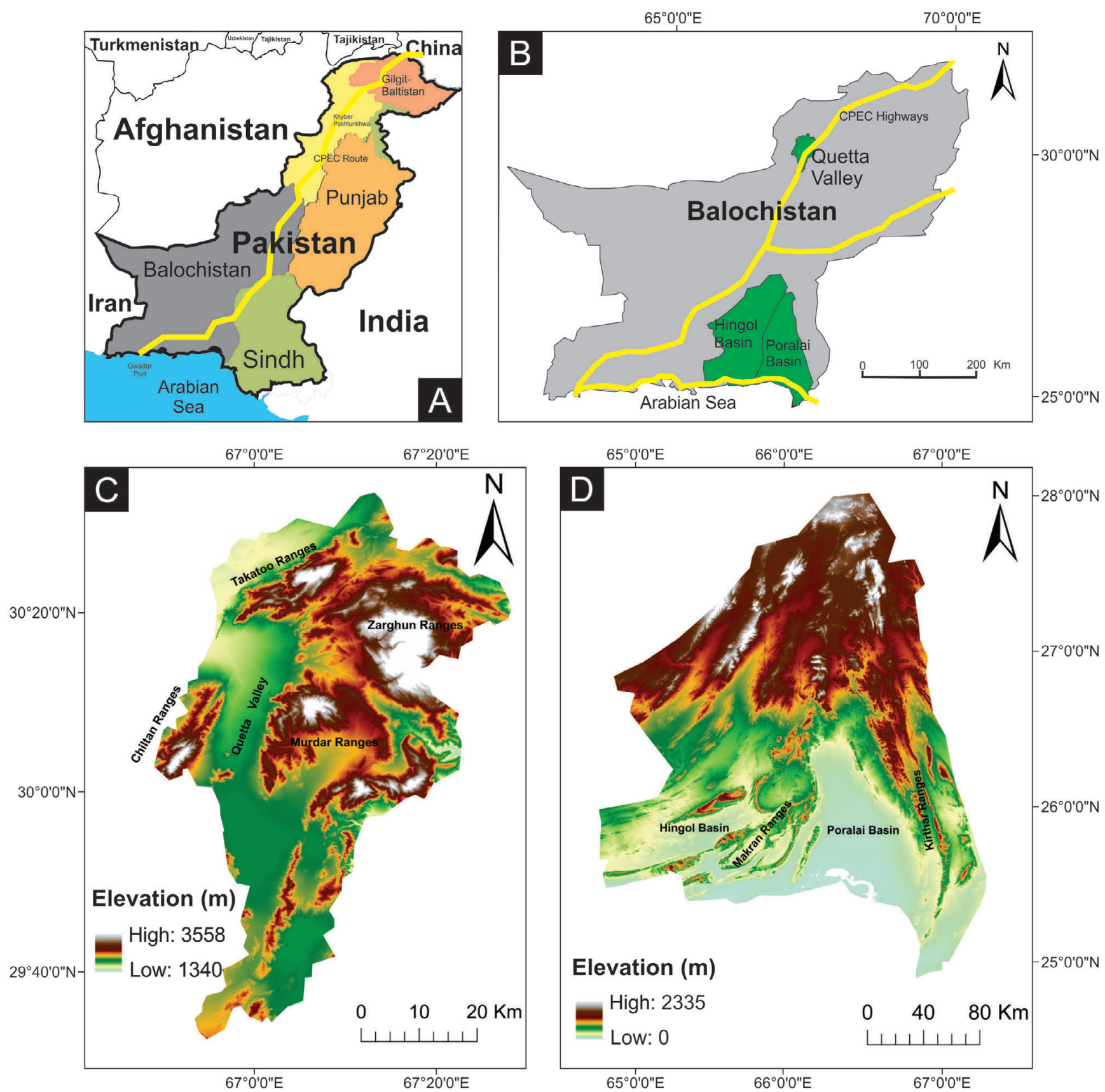

Fig. 1 - Location map of the study area. A) Pakistan, B) Balochistan. C) Quetta Valley, D) Poralai and Hingol Basins digital elevation model. (Yellow line in A and B shows the proposed CPEC, China Pakistan Economic Corridor, route).

Fig. 1 - Ubicazione dell'area di studio. Modello digitale del terreno per A) Pakistan, B) Balochistan, C) Valle di Quetta, D) bacini di Poralai e Hingol. (La linea gialla in A e B mostra la CPEC (China Pakistan Economic Corridor) proposta).

The successfully used MAR techniques in Balochistan include leaky dams, ditches, furrows, terraces and trenches which along with effective watershed management ameliorated the water table and reduced soil erosion in Balochistan (Ashraf and Sheikh 2017). Despite its effectiveness, MAR techniques are applied only in few areas and the rest of the declining groundwater resources are left unmanaged.

Quetta is the largest population centre and the capital city of the province of Balochistan with an extreme freshwater shortage. It is located $1650 \mathrm{~m}$ above sea level and surrounded by Murdar, Zargoon, Chiltan and Takatoo Ranges (Umar et al. 2014). The average annual precipitation is $210 \mathrm{~mm}$ and the average temperature ranges from 5 to $30^{\circ} \mathrm{C}$. In the Quetta Valley there are two main aquifers, one is composed of unconsolidated Quaternary alluvial sediments (200$1000 \mathrm{~m}$ thick) which covers most of the valley and the other is a bedrock aquifer (200-1500 m thick) (Ahmad et al. 2019). The bedrock aquifer is composed of limestone of 
Chiltan (Jurassic), Kirthar (Tertiary) and Dungan (Tertiary) formations. The permeability of these bedrock aquifers is enhanced by karstification and fracturing (Sagintayev et al. 2012). The valley floor alluvial aquifer is recharged from run-off, infiltration from precipitation and inflow from the bedrock aquifer. The bedrock aquifer is recharged in the mountains where these formations are exposed (Khan et al. 2010).

Hingol and Poralai Basins are located in the southern-most part of Balochistan and the Makran Coastal Range separates the two. In Hingol Basin annual average precipitation is 80$170 \mathrm{~mm}$ and the temperature ranges from 5 to $38^{\circ} \mathrm{C}$. In Poralai Basin the average annual precipitation and temperature ranges are $150-200 \mathrm{~mm}$ and 10 to $35{ }^{\circ} \mathrm{C}$, respectively. Elevation increases towards the north where the highest elevation is in Kirthar Ranges $(2335 \mathrm{~m})$. These coastal basins are composed of alluvium (Holocene), conglomerate (Pleistocene), shale (Eocene to Triassic) and limestone (Eocene to Triassic). This area is poorly studied, but most of the tube wells are fed by an alluvial aquifer, which has high groundwater potential, followed by conglomerate and limestone aquifers (Ahmed et al. 2015).

The alluvial aquifer of the Poralai Basin is the highest permeability aquifer of Balochistan (Aftab 1997). The quality of groundwater is saline to highly saline (Aftab 1997) due to seawater intrusion which is observed up to $6 \mathrm{~km}$ inland (Mujtaba and Latif 2013). Poralai and Hingol basins are suffering from water table decline, seawater intrusion, and flash floods. The population of coastal areas is expected to increase rapidly because of the development of the ChinaPakistan Economic Corridor (CPEC) which will further aggravate the water-related problems (Taj et al. 2018; Ashraf and Sheikh 2017; Mujtaba and Latif 2013).

\section{Materials and methods}

The novel approach is adapted by integrating the online tools of the INOWAS platform (INOWAS 2021), remote data and traditional maps in the ArcGIS environment (ArcGIS
2018) to display MAR suitability map according to the following steps (Fig. 2):

- Narrowing down the possible MAR methods for the study area using the INOWAS platform;

- Digitizing the existing geological, soil and precipitation maps in ArcGIS;

- Producing slope, drainage density, land cover, precipitation, geology and soil map using GIS tools and remote sensing data (criteria maps);

- Constraint mapping to exclude unsuitable areas from further MAR suitability analysis;

- Ranking all of the maps based on their relative importance using Multi-Influence Factor method (Bonilla Valverde et al. 2016);

- Standardization of all the criteria;

- Weighted overlay analysis to get final MAR suitability map.

\section{MAR Method Selection Through INOWAS Platform}

The first step helped in narrowing down the possible MAR options for the study area using the online INOWAS platform (INOWAS, 2021). INOWAS has a large database of the already published MAR suitability studies (e.g. Russo et al. 2015; Bonilla Valverde et al. 2016; Steinel et al. 2016). The decisionmakers can use different filters to find desired information, e.g. literature about specific MAR methods, world locations where a particular MAR method is implemented, suitability of MAR methods according to specific conditions etc. By specifying some of the characteristics of the study area such as soil type, land use, purpose of MAR, the typical scale of the study, INOWAS provides a suggestion for the suitable MAR methods based on the database of MAR studies (Sallwey et al. 2019).

Some methods suggested by INOWAS were suitable and some were not, based on the climatic, and geomorphological conditions of Balochistan (e.g. INOWAS suggests dune filtration as a possible MAR technique, but there are no sand dunes present in the study area). The specific MAR type

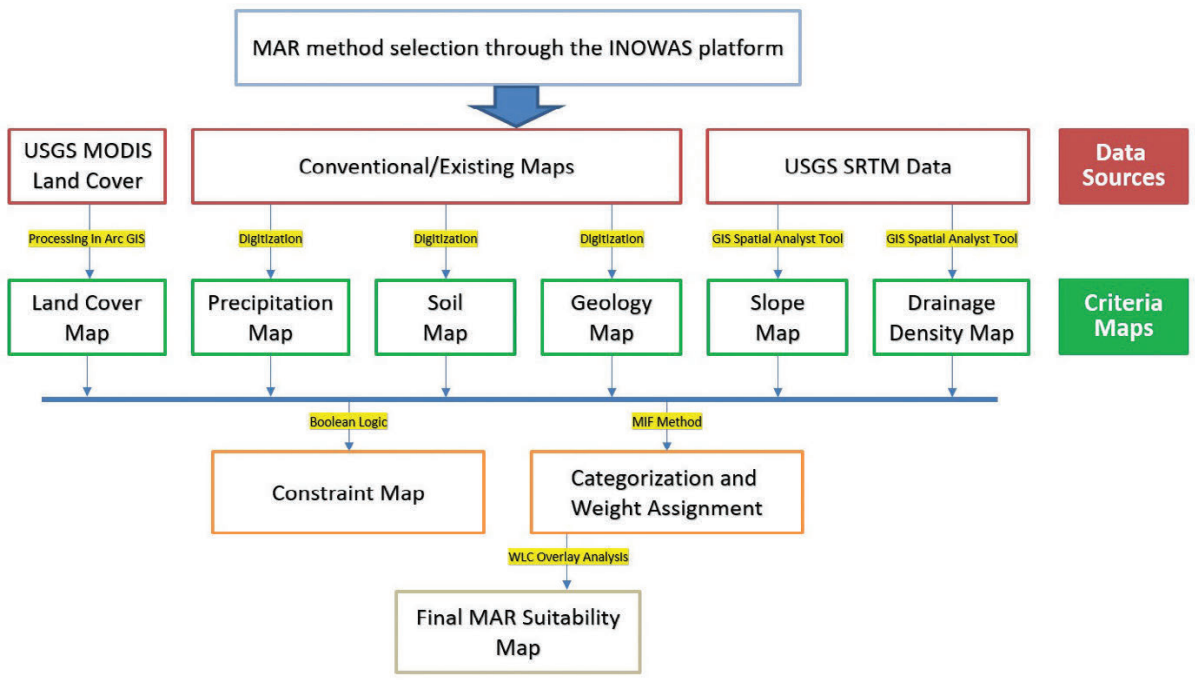

Fig. 2 - Flow chart showing different steps of the proposed approach for MAR suitability mapping.

Fig. 2 - Diagramma di flusso con i diversi step dell'approccio proposto per la mappatura dell'idoneità per l'utilizzo di tecniche MAR 
was not considered in suitability mapping in earlier studies (see e.g. Hostetler 2007; Escalante et al. 2014; Russo et al. 2015; Alraggad et al. 2010; Rahman et al. 2012; Chenini and Mammou 2010). Seven different MAR methods were suggested by INOWAS for the study area. The suitable ones included recharge trenches, ditches and furrows, rooftop harvesting, and flooding. One method, namely 'leaky dams', is not suggested by INOWAS, but has been used successfully in Balochistan, therefore it was included in the analysis. Table 1 summarizes the suitability/unsuitability of MAR methods in the context of the prevailing climatic and hydrologic conditions of the study area.

Tab. 1 - MAR methods suggested by INOWAS and their suitability for the study area.

Tab. 1 - Tecniche MAR suggerite dalla piattaforma INOWAS e relativa idoneità per l'area di studio.

\begin{tabular}{|c|l|l|}
\hline $\begin{array}{c}\text { MAR method } \\
\text { and basins }\end{array}$ & Suitability & \multicolumn{1}{|c|}{ Details } \\
\hline Unsuitable & $\begin{array}{l}\text { High temperature and } \\
\text { high sedimentation rate } \\
\text { render these methods } \\
\text { unsuitable }\end{array}$ \\
\hline Trenches & Suitable & $\begin{array}{l}\text { Low capital, operational } \\
\text { and maintenance costs }\end{array}$ \\
\hline Dubsurface Dams & Unsuitable & $\begin{array}{l}\text { Water table is very deep } \\
\text { for the most part (20-30m) }\end{array}$ \\
\hline Rooftop harvesting & Suitable & $\begin{array}{l}\text { At a household level, it is } \\
\text { an effective method }\end{array}$ \\
\hline Ditches and furrows & Suitable & $\begin{array}{l}\text { Low capital, operational } \\
\text { and maintenance costs }\end{array}$ \\
\hline Flooding & Suitable & $\begin{array}{l}\text { Useful in times of heavy } \\
\text { rainfalls to prevent damage }\end{array}$ \\
\hline
\end{tabular}

\section{Data Sources, Choice of Criteria and Preparation of Criteria Maps}

The spatial information that is used in GIS-MCDA is called criterion. Each criterion should be measurable, complete, comprehensive, non-redundant and decomposable (Malczewski \& Rinner 2015). There are three types of criteria: it can be a spatially measurable variable (e.g. slope), an attribute (e.g. land cover), or a value obtained from spatial analysis (e.g. drainage density). The number of used criteria ranges from 4 to 21 , but $90 \%$ of studies use less than 10 criteria (Sallwey et al. 2019). Saraf and Choudhury (1998) used geology, geomorphology, slope and lineaments in their suitability analysis, while ignoring drainage density and land use maps. Drainage density, although does not impact the infiltration, is a good indicator of permeability of the underlying lithology. Other studies, e.g. Rahman et al. (2012) used a very large set of criteria including groundwater quality and water table depth. By increasing the number of criteria, the accuracy of the MAR suitability map increases, but the data availability and quality also influences it. Hence, it works for small areas where high resolution is needed. Precipitation map is only used in one study by Chenini and Mammou (2010) to the best of our knowledge. Precipitation although does not affect the intrinsic suitability of an area, it has an important influence on the availability of water and should be added in large scale MAR suitability mapping as a potential source of water. Bonilla Valverde et al. (2016) in the suitability mapping of Costa Rica used hydrogeological aptitude (aquifer type, depth, extent, porosity, and permeability) instead of surface geology, which increases the effectiveness of the map. However, the availability of detailed data on the hydrogeological aptitude of poorly investigated areas is rare. Also, the land cover map is not integrated into the study of Bonilla Valverde et al. (2016). This is a crucial element for suitability analysis.

The six individual criteria maps used in the present study (soil, geology, drainage density, slope, precipitation and land use maps) are easily available for any area. Data may be derived either from national geological surveys and/or created easily using freely available remote sensing data.

Once the criteria are selected the next step is to find data sources for them. Three data sources were used including USGS MODIS Land Cover (USGS Earth Explorer 2021), SRTM (Shuttle Radar Topography Mission) data and existing maps. Soil, geological, and precipitation maps were produced by digitizing the existing maps of Balochistan (Lahore 1993; Aftab 1997; Maldonado et al. 2011; Ahmed et al. 2018). Drainage density was calculated in ArcGIS using spatial analyst tool, based on DEM, flow accumulation and stream links (Dragičević et al. 2019; ESRI 2005). The slope map was prepared from SRTM DEM (USGS Earth Explorer

Tab. 2 - Details of data used in GIS-MCDA.

Tab. 2 - Dettagli dei dati utilizzati per l'approccio GIS-MCDA.

\begin{tabular}{|c|c|c|}
\hline Map & Source & Scale/Resolution \\
\hline Geological Map & For Poralai and Hingol Basins: Aftab 1997 & $1: 250000$ \\
& ASTER DEM (USGS Earth Explorer 2021) & 300000 \\
\hline Drainage Density & ASTER DEM (USGS Earth Explorer 2021) & $30 \mathrm{~m}$ \\
\hline Slope & Soil Survey of Pakistan (Lahore 1993) & $1: 200000$ \\
\hline Soil Map & MODIS Landcover data (USGS Earth Explorer 2021) & Ahmed et al. 2018 \\
\hline Land Use & Ahm & \\
\hline Precipitation Map & & \\
\hline
\end{tabular}


2021) using the spatial analyst tool (Magesh et al. 2012). The land cover map was produced from USGS MODIS land cover data (USGS Earth Explorer 2021). Table 2 reports the sources and resolution of each map used in GIS-MCDA for the Balochistan.

In the following, a short description of the criteria used in the present study is reported.

\section{A) Geology}

The major lithologies that underlie the study area are limestone, shale and alluvial sediments. The infiltration rate is high for alluvium, conglomerate, and karstic/fractured limestone and low for shale and argillaceous limestone.

\section{B) Slope}

The slope is an important criterion for MAR suitability mapping. The flat surface provides ideal conditions for infiltration. As the slope increases the run-off increases and infiltration decreases. In most of the study area slope is less than $10 \%$.

\section{C) Drainage density}

Drainage density is inversely related to the permeability of the underlying material. Less permeable material leads to high run-off and high drainage density. For most of the area, drainage density is less than $3.5 \mathrm{~km} / \mathrm{km}^{2}$ which is good for MAR implementation (Shankar and Mohan 2005).

\section{D) Soil}

Soil plays the role of purifying the surface water as it infiltrates. Areas without a soil cover have low suitability for the implementation of the intended MAR methods for this study because the absence of soil cover poses a great threat of contamination. This risk increases further in the case of karstic aquifers where the purification of water is reduced to almost zero. However, areas with no soil cover are not excluded from suitability mapping because purification may also occur when water infiltrates through rocks, not only soils. The main soil type present in the study area is sandy loam which shows fairly good hydraulic conductivity $\left(1.1 * 10^{-5} \mathrm{~m} / \mathrm{s}\right)($ Sagintayev 2010).

\section{E) Precipitation}

The higher the precipitation the more would be the availability of water for MAR, thus areas with high rainfall are considered as of high suitability for MAR.

\section{F) Land cover}

Sparsely vegetated land is considered best for recharge purposes as it offers large areas for infiltration without creating many conflicts. The second-best alternative is pastureland. It normally has a good infiltration rate and economic loss is also not very high. The third best alternative is cultivated land. The intrinsic quality of cultivated land such as good soils with high infiltration capacity, and availability of water make it a good alternative. However, it is difficult to convince the owners to provide their land (which has a regular use in their farming activity) for MAR.

\section{Constraint Mapping}

As a third step, constraint mapping was used based on Boolean logic to screen out the areas which are not feasible (indicated by 0) for MAR applications (Rahman et al. 2012). Here, areas with a slope higher than $40 \%$ are discarded as unsuitable because the chances of potential infiltration are very low (Bonilla Valverde et al. 2016). The other constraint used in this study is the presence of urban areas as the quality of water is poor and the chances of infiltration are low because of built-ups (Alraggad et al. 2010). Both the constraint maps are integrated to get the final constraint map which is used as a mask for the suitability maps.

\section{Categorization and Weight Assignment Through Multi Influencing Factor (MIF) Method}

Even though GIS-MCDA is widely used for MAR suitability mapping, there is no consensus on the selection of criteria and assigning values to them (Sallwey et al. 2019). This process in this study is based on the knowledge of the study area, availability of data and purpose of the study. Each criterion map is divided into suitability classes with respect to MAR. A higher score indicates high suitability and a lower score indicates low suitability. As part of the proposed approach, criteria weight assignment through the MIF method (Bonilla Valverde et al. 2016) is worked out for MAR suitability evaluation. In MIF, the more a criterion influences the other criteria the higher its score is, and hence a higher weight is assigned to it. All the major (solid line, score 1) and minor influences (dashed line, score 0.5) of criteria, the total score of each criterion and their weights are given in Figure 3. All the scores are added for each criterion and the final weight is calculated. Geology has a major influence on drainage density (Shaban et al. 2006), landcover, soil (Magesh et al. 2012) and the recharge processes (Bonilla et al. 2016). Soil type has a major influence on the recharge and a minor influence on drainage density (Bonilla et al. 2016). The slope of the area influences the land cover, soil (as erosion is high on steep slopes; Magesh et al. 2012) and drainage density (Singh et al. 2013). Steeper slopes are associated with high drainage density and low infiltration (Bonilla et al. 2016; Singh et al. 2013). Drainage density is the indicator of infiltration, so its influence is considered minor (Bonilla et al. 2016). The type of land cover affects the availability of land for MAR operation and the infiltration capacity of the ground, so it is assigned a major influence on recharge. Precipitation is included in the present study and assigned to have a minor influence on MAR.

\section{Weighted Overlay Analysis}

The weighted linear combination is used for overlay analysis. The final MAR suitability map is obtained by overlaying all the criteria maps according to their respective ranges/common scale (0-10), weights and final suitability class in the spatial analyst tool of ArcGIS. 


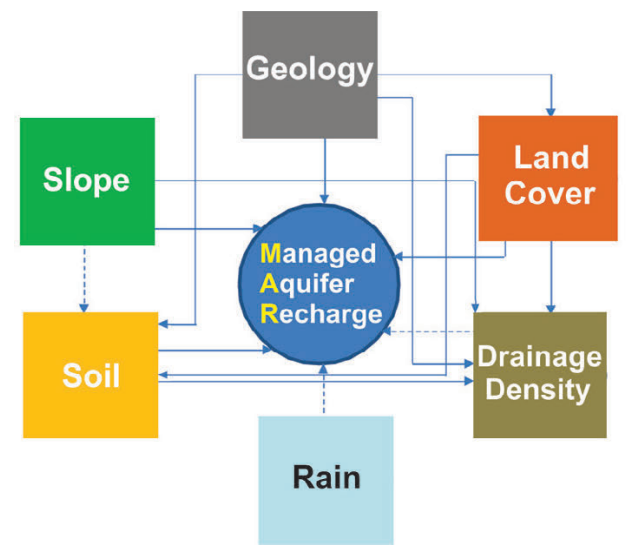

\section{Results and Interpretation}

As a result of the analysis, criteria and final suitability maps were provided for both of the study areas (Figs 4, 5 , $6,7)$. Based on the criteria suitability maps, the effect of all parameters can be followed on final MAR suitability.

For Poralai and Hingol Basins, based on geology, the northwestern and the southeastern part of the area is suitable or highly suitable (Fig. 4A). Considering the slope, two-thirds of the area shows low or very low suitability (Fig. 4B) due to the mountains present in this area. From the perspective of soil cover, sandy and gravelly loam is preferred, thus the southern part is more suitable (Fig. 4C). Low drainage density is suitable for MAR application,

\begin{tabular}{|l|l|l|}
\hline Criterion & Score & Weight \\
\hline Geology & $1+1+1+1=4$ & $32 \%$ \\
\hline Slope & $1+1+0.5=2.5$ & $20 \%$ \\
\hline Drainage Density & 0.5 & $04 \%$ \\
\hline Soil & $1+1+1=3$ & $24 \%$ \\
\hline Rain & 0.5 & $04 \%$ \\
\hline Land Cover & 2 & $16 \%$ \\
\hline Total & $\mathbf{1 2 . 5}$ & $100 \%$ \\
\hline
\end{tabular}

Fig. 3 - Criteria weight assignment through Multi Influencing Factor (MIF) method for MAR suitability evaluation.

Fig. 3 - Assegnazione dei pesi utilizzando il metodo Multi Influencing Factor (MIF) per la valutazione dell'idoneità alle tecniche MAR.

therefore the southern part of Poralai and Hingol Basins with drainage density of more than $6 \mathrm{~km} / \mathrm{km}^{2}$ has low suitability (Fig. 4D). The eastern part of the area has a higher average annual precipitation thus has higher suitability (Fig. 4E). Most of the area is sparsely vegetated and without buildups, therefore was assigned a high suitability class (Fig. 4F).

For Quetta Valley, based on geology, most of the area is highly suitable or moderately suitable because of the widespread presence of alluvium and karstic limestone (Fig. 5A). Considering the slope, the eastern half of the area has very low suitability because of the presence of steep slopes $(>10 \%)$ (Fig. 5B). The presence of sandy and gravelly loam made the western part more suitable (Fig. 5C). The areas


E

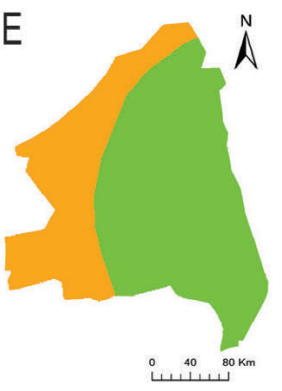

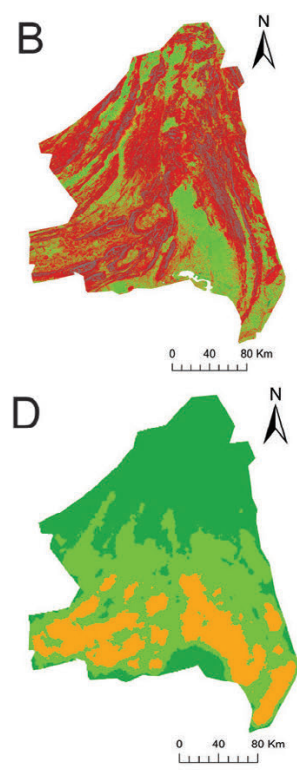

$\mathrm{F}$

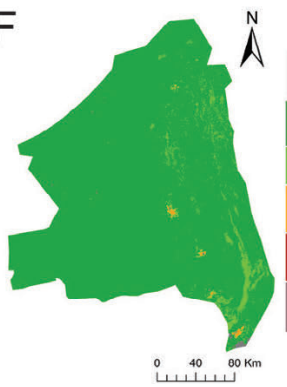



Value/Common scale Suitability Class

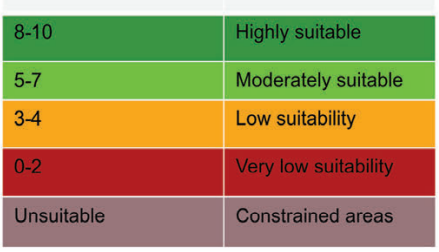

Fig. 4 - Criteria suitability maps and criteria standardization for Poralai and Hingol Basins A) Geology, B) Slope, C) Soil, D) Drainage density, E) Precipitation and F) Land cover.

Fig. 4 - Mappe di idoneità e standardizzazione dei criteri per i bacini di Poralai e Hingol A) Geologia, B) Pendenza, C) Suolo, D) Densità di drenaggio, E) Precipitazioni e F) Copertura del suolo. 

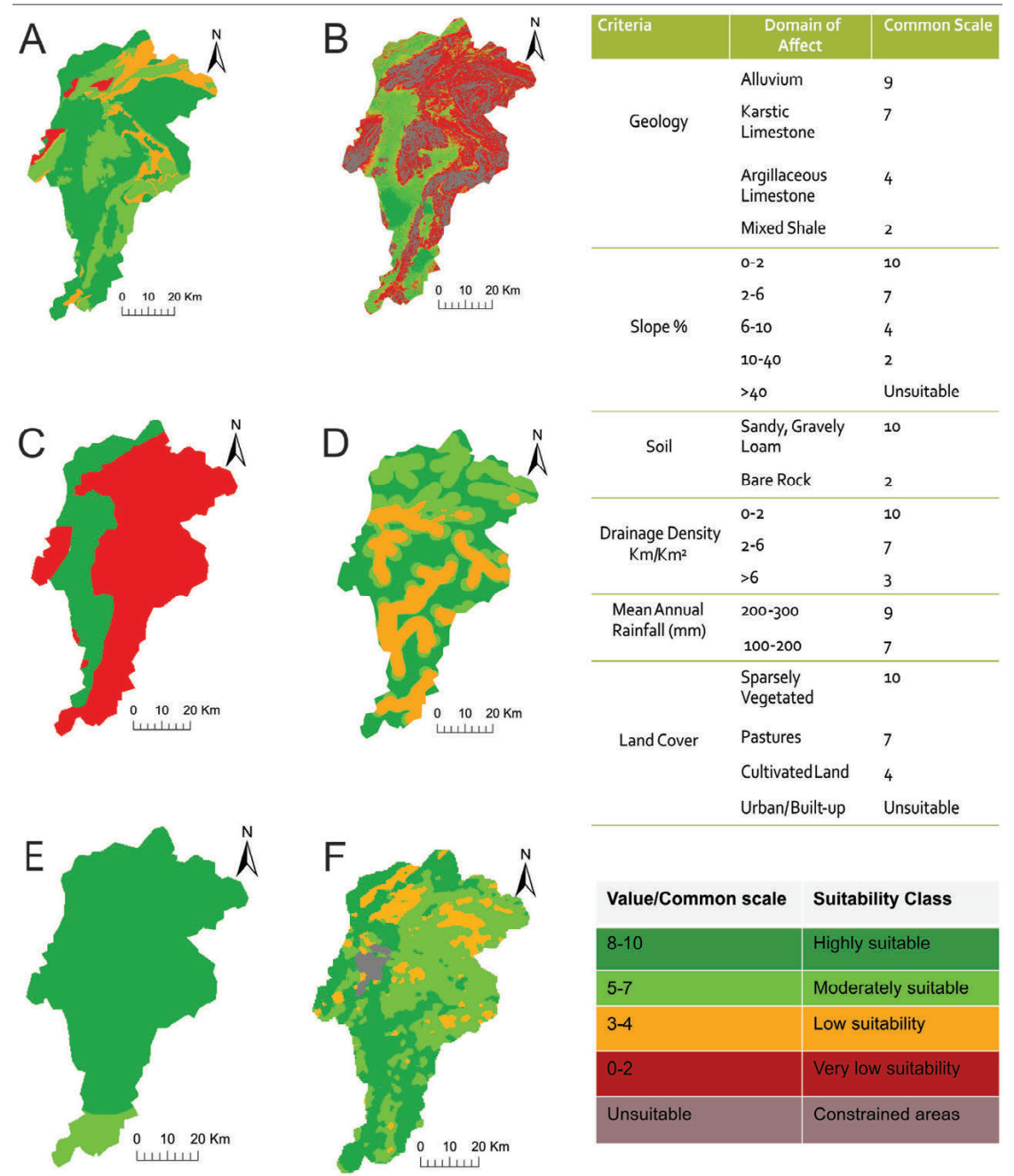

Fig. 5 - Criteria suitability maps and criteria standardization for Quetta Valley A) Geology, B) Slope, C) Soil, D) Drainage density, E) Precipitation and F) Land cover.

Fig. 5 - Mappe di idoneità e standardizzazione dei criteri per la Valle di Quetta A) Geologia, B) Pendenza, C) Suolo, D) Densità di drenaggio, E) Precipitazioni e F) Copertura del suolo.

with high drainage density are more prevalent in the southern part of Quetta Valley and show low suitability (Fig. 5D). Most of the area has high suitability with regards to precipitation except the southern tip of the area which has moderate suitability (Fig. 5E). Most of the area has sparse vegetation or is covered by pastures, therefore has high to moderate suitability, except for Quetta city which is densely populated therefore excluded from the analysis. In the northern part, some areas are cultivated, thus assigned low suitability (Fig. 5F).

The major influence noticed on the final MAR suitability maps of the study area both in Quetta Valley and Poralai and Hingol Basins is related to geology and soil (Figs. 4, 5, 6, 7). The areas with relatively high suitability are underlain by thick alluvium in both areas. The presence of soil has a major impact on MAR suitability, as it purifies the infiltrating water by increasing the travel time of surface water to reach the aquifer. The topsoil layer becomes crucially important in the case of limestone aquifers (abundant in the study area). If the soil layer is absent on top of limestone, water quickly seeps down due to fractures and enhanced karstic porosity, and contaminates the aquifer. Slope is the third most influential factor, e.g. the eastern part of Poralai Basin, despite the presence of optimum conditions for MAR suitability with respect to other criteria, falls in the low MAR suitability class because of the presence of steep slope. Most of the study area is sparcely vegetated or covered with pastures and the urban centers are absent except for the Quetta city (Fig. 5), thus this criterion has lower influence on the final suitability maps. Precipitation has a minor influence on MAR suitability, e.g. the northern portion of Hingol Basin lies in 'very low suitability' class for precipitation (Fig. 4C) but its final MAR suitability class is 'moderate' to 'high'. Similarly, the 'suitability class' of drainage density of the criteria map shows no strong correlation with the final MAR suitability maps of the study area.

The final MAR suitability map (Figs. 6 and 7) shows that most of the Poralai Basin has a high potential for MAR applications followed by Hingol Basin (10\% of the area lies in a high suitability zone while $40 \%$ of the area lies in a moderate suitability zone). The MAR suitability map of Quetta Valley shows that less than $5 \%$ of the area falls in high suitability while $40 \%$ of the area falls in the moderate suitability zone. The rest belongs to low and very low MAR suitability zones. Despite the presence of thick alluvium both in Quetta Valley and Poralai Basin, the presence of urban built-ups in Quetta Valley decreases its suitability. In both study areas, the high 


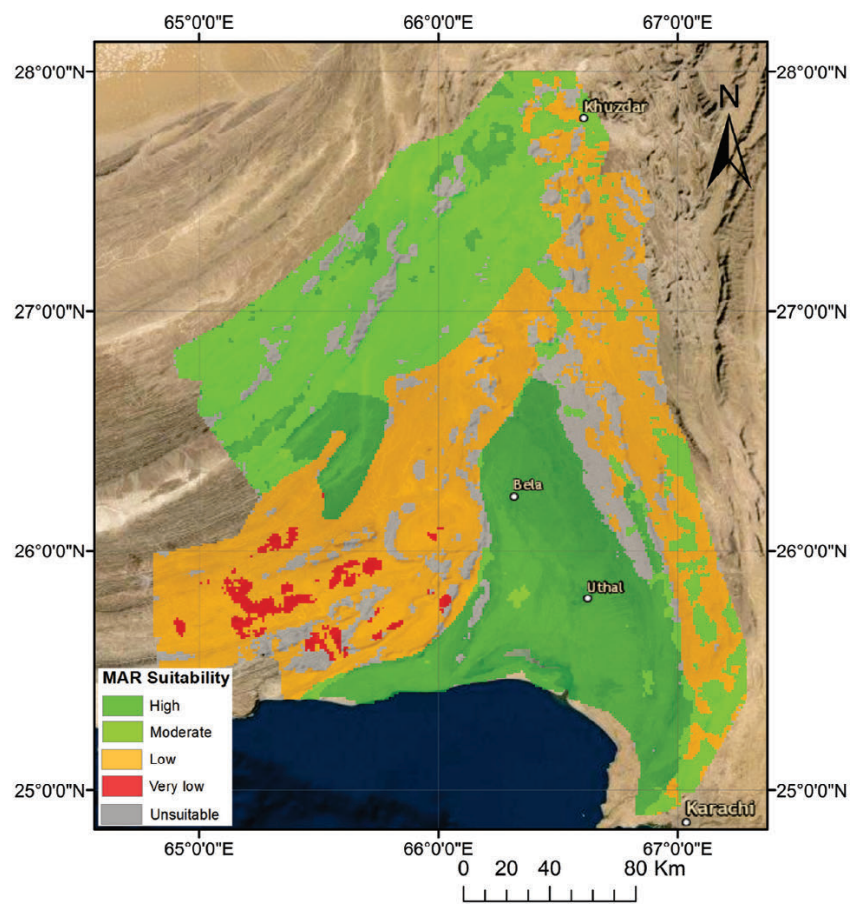

Fig. 6 - MAR suitability map of Poralai and Hingol Basins.

Fig. 6 - Mappa di idoneità per l'utilizzo di tecniche MAR per i bacini di Poralai e Hingol.



Fig. 7 - MAR suitability map of Quetta Valley.

Fig. 7 - Mappa di idoneità per l'utilizzo di tecniche MAR per la Valle di Quetta.
MAR suitability zones' distribution is concentrated where thick soil, alluvial sediments, and gentle slope are prevailing, which shows the pivotal role of these criteria. The source of water can include, precipitation, rural run-off, surface water from intermitted streams, treated wastewater, and desalinized water. This decision may only be based on the results of subsequent local studies. Unfortunately, water quality data at this scale is not available for the study area.

\section{Discussion}

\section{Evaluation of the approach}

In the line of the applied methods, INOWAS has been found helpful while deciding the MAR options for the area. However, its accuracy is not high enough. Factors such as temperature, precipitation and water table depth are not considered in the decision. For example, for the present study one MAR option suggested by INOWAS is subsurface dams, but the water table in the area is too deep for it to be a feasible option. The selection could be more accurate by adding the options 1) temperature of the area and its seasonal variability, 2) precipitation, and its seasonal variability and 3) depth to the water table.

The MAR methods considered in this study include ditches and furrows, leaky dams, and trenches. Rainwater harvesting is also a possible method, but for its application, we need to take into consideration different parameters such as the quality of the water collected from rooftops of city houses. It might be of poor quality and can pollute the aquifer easily, therefore this method should be applied with caution.

The urban areas are considered as constraints (unsuitable) in this study, because of the pollution and unavailability of suitable surfaces. However, if the water is treated prior to the injection into the aquifer, MAR can be applied in urban areas too. Areas with low suitability ranking should not be considered unsuitable for MAR implementation, because MAR suitability mapping only indicates the relative suitability of different parts of an area.

This study shows the intrinsic suitability of an area for MAR applications based on factors which influences the infiltration and storage of water in an aquifer. The quality of water is not considered as a criterion. So an area that ranks high on MAR suitability scale can be located in the proximity of polluted surface water.

\section{Limitations}

This is a large-scale study with the major intention to assemble the MAR suitability map to classify and prioritize areas in Quetta Valley, and Poralai and Hingol Basins for further detailed MAR studies. This map is in no way appropriate to make a final decision on the construction of a MAR scheme in such areas. Factors such as quality of water, site access, depth to the water table, and political and economic constraints which greatly affect the final decision of MAR implementation are not considered in this study. 


\section{Further Steps}

It is expected that the results of this study can be incorporated in an environment-friendly water management plan for the water-starved province. Future studies can focus on local-scale high-resolution MAR suitability analysis based on this preliminary results. Availability of water table depth data and detailed information on the hydraulic conductivity of the soil and data for water quality will play an important role for local scale high-resolution MAR suitability maps. Data about the use of water can further refine the analysis, as the required quality of water for drinking purposes, agriculture and industrial use vary.

The steps followed in the present study can be replicated for MAR suitability mapping of any arid-semiarid area with remote sensing data.

The socioeconomic aspects such as cost, land requirement, knowledge, and acceptance of MAR by the public, etc. play an important role in the success of MAR as well (Maliva 2014; Le Corre et al. 2012). These factors should be considered while planning a focused and detailed MAR suitability analysis.

Currently, the proportion of MAR projects in arid-semiarid regions like Balochistan is quite low despite the urgent need for MAR implementation is in such areas. It shows us the opportunities of MAR in these areas, which can mitigate the water crisis and help expedite sustainable development.

\section{Conclusions}

MAR is an effective method to deal with water scarcity, a major challenge of the $21^{\text {st }}$ century. Depending on the hydrogeological characteristics of an area, various methods are used to intentionally recharge groundwater. MAR suitability mapping by integrating various influencing factors provides a comprehensive view of a study area and divides it into zones of different ranking (Rahman et al. 2012). This top-down approach is useful to delineate the areas for more focused MAR analysis as opposed to the conventional approach of site-specific studies.

In the present study, the proposed approach combining the use of the INOWAS platform with MIF and GIS-MCDA methods is proposed. The approach is based on two key considerations 1) data availability, 2) showing a comprehensive picture of an arid-semiarid area for MAR suitability. Using the MIF method among the six criteria, the highest weigh is assigned to geology and soil, which combined account for $56 \%$ of the total weight. Based on the application of the combined approach, the MAR suitability maps produced divide the study areas, Quetta Valley, Poralai and Hingol Basins, into four MAR suitability zones, namely highly suitable, moderately suitable, low suitability, and very low suitability.

The MAR suitability map shows that most of the Poralai Basin is located in high suitability zone while $40 \%$ of the Hingol Basin and Quetta Valley lies in moderate suitability zones. MAR suitability maps produced in this study can act as a basic guide to performing focused studies for MAR implementation. The densely populated Quetta city is located in a moderate MAR suitability zone, therefore if further research is conducted and MAR is applied, it could contribute to the solution of water shortage and land subsidence of the city. The coastal Poralai Basin that is suffering from seawater intrusion falls in a high MAR suitability zone, which is a positive sign for the implementation of MAR projects for these areas to reduce seawater intrusion.

These MAR suitability maps, which are the first ones made for Pakistan, hold the potential to be integrated into sustainable groundwater management plans for Balochistan and are intended to be used as a basis for further studies and field investigation for MAR site selection. The combined approach, methodology and results gained from this study can be used as auxiliary for MAR suitability mapping for any arid and semiarid region.

\section{Acknowledgements}

The authors would like to thank the two reviewers and the editors for improving the manuscript with their useful comments and suggestions. This research is part of the ENeRAG project that has received funding from the European Union's Horizon 2020 research and innovation program under grant agreement No 810980. Sikandar Hayat is thankful to Tempus Public Foundation and Government of Hungary for providing Stipendium Hungaricum MSc scholarship to study at Eötvös Loránd University, Budapest, Hungary. This research is partly supported by the National Research, Development and Innovation Office, Ministry for Innovation and Technology, Hungary through Cooperative Doctoral Program (KDP) scholarship awarded to Zsóka Szabó.

\section{Competing interest}

The authors declare no competing interest.

\section{Author contributions}

Collection of data, Hayat S; data processing, Hayat S; interpretation of results, Hayat S, Szabó Z, Mádl-Szőnyi J; writing-original draft preparation, Hayat S; writing-review and editing, Szabó Z, Tóth, Á, Mádl-Szőnyi J; visualization, Hayat S and Szabó Z; supervision, MádlSzőnyi J; project administration, Mádl-Szőnyi J. All authors have read and agreed to the published version of the manuscript.

\section{Additional information}

Supplementary information is available for this paper at https://doi.org/10.7343/as-2021-505

Reprint and permission information are available writing to acquesotterranee@anipapozzi.it

Publisher's note Associazione Acque Sotterranee remains neutral with regard to jurisdictional claims in published maps and institutional affiliations. 


\section{REFERENCES}

Aeschbach-Hertig W, Gleeson T (2012) Regional strategies for the accelerating global problem of groundwater depletion. Nature Geoscience 5:853-861. doi:10.1038/ngeo1617

Aftab S (1997) Hydrogeology and groundwater resources of Balochistan, Pakistan; an overview. Acta Mineralogica Pakistanica 8:30-38.

Ahmad W, Choi M, Kim S, Kim D (2017) Detection of land subsidence due to excessive groundwater use varying with different land cover types in Quetta valley, Pakistan using ESA-sentinel satellite data. Natural Hazards and Earth System Sciences Discussions 1-21. doi:10.5194/nhess-2017-234

Ahmad W, Choi M, Kim S, Kim D (2019) Detection of land subsidence and its relationship with land cover types using ESA Sentinel satellite data: a case study of Quetta Valley, Pakistan. International Journal of Remote Sensing 40:9572-9603. doi:10.1080/01431161.2 019.1633704

Ahmed K, Shahid S, bin Harun S, Ismail T, Nawaz N, Shamsudin S. (2015) Assessment of groundwater potential zones in an arid region based on catastrophe theory. Earth Science Informatics 8:539-549. doi:10.1007/s12145-014-0173-3

Ahmed K, Shahid S, Ismail T, Nawaz N, Wang XJ (2018) Absolute homogeneity assessment of precipitation time series in an arid region of Pakistan. Atmósfera 31:301-316. doi:10.20937/atm.2018.31.03.06

Alraggad M, Jasem H (2010) Managed aquifer recharge (MAR) through surface infiltration in the Azraq basin/Jordan. Journal of Water Resource and Protection 2:1057. doi:10.4236/jwarp.2010.212125

ArcGIS (2018): ArcGIS Desktop 10.6. Available from: https://www.esri. com/en-us/arcgis/products/arcgis-desktop/resources - last accessed $14 / 09 / 2021$

Arshad M, Guillaume JH, Ross A (2014) Assessing the feasibility of managed aquifer recharge for irrigation under uncertainty. Water 6: 2748-2769. doi:10.3390/w6092748

Ashraf M, Sheikh AA (2017) Sustainable Groundwater Management in Balochistan. Pakistan Council of Research in Water Resources (PCRWR), Islamabad.

Bonilla Valverde JP, Blank C, Roidt M, Schneider L, Stefan C (2016) Application of a GIS multi-criteria decision analysis for the identification of intrinsic suitable sites in Costa Rica for the application of managed aquifer recharge (MAR) through spreading methods. Water 8:391. doi:10.3390/w8090391

Bouwer H (2002) Artificial recharge of groundwater: hydrogeology and engineering. Hydrogeology Journal 10:21-142. doi:10.1007/s10040001-0182-4

Chenini I, Mammou AB (2010) Groundwater recharge study in arid region: an approach using GIS techniques and numerical modeling. Computers \& Geosciences 36:801-817. doi:10.1016/j. cageo.2009.06.014

Dillon P, Toze S, Page D, Vanderzalm J, Bekele E, Sidhu J, RinckPfeiffer S (2010) Managed aquifer recharge: rediscovering nature as a leading-edge technology. Water Science and Technology 62:23382345. doi:10.2166/wst.2010.444

Dillon P, Stuyfzand P, Grischek T, Lluria M, Pyne RDG, Jain RC, Bear J, Schwarz J, Wang W, Fernandez E, Stefan C, Pettenati M, van der Gun J, Sprenger C, Massmann G, Scanlon BR, Xanke J, Jokela P, Zheng Y, Rossetto R, Shamrukh M, Pavelic P, Murray E, Ross A, Bonilla Valverde JP, Palma Nava A, Ansems N, Posavec K, Ha K, Martin R, Sapiano M (2019) Sixty years of global progress in managed aquifer recharge. Hydrogeology Journal 27:1-30. doi: $10.1007 / \mathrm{s} 10040-018-1841-z$

Dragičević N, Karleuša B, Ožanić N (2019) Different approaches to estimation of drainage density and their effect on the erosion potential method. Water 11:593. doi:10.3390/w11030593

Escalante EF, Gil RC, San Miguel Fraile MÁ, Serrano FS (2014) Economic assessment of opportunities for managed aquifer recharge techniques in Spain using an Advanced Geographic Information System (GIS). Water 6:2021-2040. doi:10.3390/w6072021
Escalante EF, Sauto JSS, Gil RC (2019) Sites and Indicators of MAR as a Successful Tool to Mitigate Climate Change Effects in Spain. Water 11:1943. doi:10.3390/w11091943

ESRI (2005) Arc Hydro Tools - Tutorial. Environmental Systems Research Institute, Redlands, CA, USA.

Fishman RM, Siegfried T, Raj P, Modi V, Lall U (2011) Overextraction from shallow bedrock versus deep alluvial aquifers: Reliability versus sustainability considerations for India's groundwater irrigation. Water Resources Research 47: W00L05. doi:10.1029/2011WR010617

Foster SSD, Chilton PJ (2003) Groundwater: the processes and global significance of aquifer degradation. Philosophical Transactions of the Royal Society of London. Series B: Biological Sciences 358:19571972. doi:10.1098/rstb.2003.1380

Giordano M (2009) Global groundwater? Issues and solutions. Annual review of Environment and Resources 34:153-178. doi:10.1146/ annurev.environ.030308.100251

Giordano M, Villholth KG (eds.) (2007) The agricultural groundwater revolution: opportunities and threats to development (Vol. 3). CABI.

Hostetler S (2007) Water Banking. Australian Government, Bureau of Rural Sciences, Canberra.

INOWAS (2021) Free web-based modelling platform for planning, management and optimisation of managed aquifer recharge (MAR). Available from: https://www.inowas.com - last accessed 27/02/2021

Khan AS, Khan SD, Kakar DM (2013) Land subsidence and declining water resources in Quetta Valley, Pakistan. Environmental Earth Sciences 70:2719-2727. doi:10.1007/s12665-013-2328-9

Khan SD, Mahmood K, Sultan MI, Khan AS, Xiong Y, Sagintayev Z (2010) Trace element geochemistry of groundwater from Quetta Valley, western Pakistan. Environmental Earth Sciences 60:573582. doi:10.1007/s12665-009-0197-z

Lahore (1993) Pakistan. Generalized Soil Map. Available from: https:// esdac.jrc.ec.europa.eu/content/pakistan-generalized-soil-map - last accessed 14/09/2021

Le Corre K, Baggett S, Muro M, Jeffrey P (2012) Risk perception and communication for managed aquifer recharge. In: Kazner C, Wintgens T, Dillon P (eds.) Water Reclamation Technologies for Safe Managed Aquifer Recharge, IWA Publishing, London.

Magesh NS, Chandrasekar N, Soundranayagam JP (2012) Delineation of groundwater potential zones in Theni district, Tamil Nadu, using remote sensing, GIS and MIF techniques. Geoscience Frontiers 3:189-196. doi:10.1016/j.gsf.2011.10.007

Majeed A, Qureshi JD (2000) Balochistan Conservation Strategy: Background Paper, IUCN-The World Conservation Union, Pakistan.

Malczewski J (2006) GIS-based multicriteria decision analysis: a survey of the literature. International Journal of Geographical Information Science 20:703-726. doi:10.1080/13658810600661508

Maldonado F, Mengal JM, Khan SH, Thomas J-C (2011) Digital Geologic Map and Landsat Image Map of Parts of Loralai, Sibi, Quetta, and Khuzar Divisions, Balochistan Province, West-Central Pakistan. USGS Open-File Report 2100-1093. Available from: https://pubs.usgs.gov/of/2011/1093/ - last accessed 13/01/2021

Maliva R, Missimer T (2012) Arid Lands Water Evaluation and Management. Springer, Berlin, Heidelberg. doi:10.1007/978-3642-29104-3

Maliva RG (2014) Economics of managed aquifer recharge. Water 6:1257-1279. doi:10.3390/w6051257

Melesse AM, Weng Q, Thenkabail PS, Senay, GB (2007) Remote sensing sensors and applications in environmental resources mapping and modelling. Sensors 7:3209-3241. doi:10.3390/s7123209

Mujtaba U, Latif MS (2013) Delineation of sea water intrusion into freshwater aquifer in Bela Plain, coastal area of Pakistan using analytical techniques. Research Journal of Environmental Sciences 7:38. doi:10.3923/rjes.2013.38.58 
Ozturk D, Batuk F (2011) Implementation of GIS-based multicriteria decision analysis with VB in ArcGIS. International Journal of Information Technology \& Decision Making 10:1023-1042. doi:10.1142/S0219622011004695

Rahman MA, Rusteberg B, Gogu R, Ferreira JL, Sauter M (2012) A new spatial multi-criteria decision support tool for site selection for implementation of managed aquifer recharge. Journal of Environmental Management 99: 61-75. doi:10.1016/j. jenvman.2012.01.003

Raviraj A, Kuruppath N, Kannan B (2017) Identification of potential groundwater recharge zones using remote sensing and geographical information system in Amaravathy basin. Journal of Remote Sensing and GIS 6:1-10. doi:10.4172/2469-4134.1000213

Red Cross (2005) Pakistan: floods in Baluchistan. Information bulletin $\mathrm{n}^{\circ} 1$, Pakistan Red Crescent Society, Federation's Disaster Relief Emergency Group, Quetta. Available from: https://reliefweb.int/ report/pakistan/pakistan-floods-information-bulletin-n-1-1 - last accessed 04/03/2021

Russo TA, Fisher AT, Lockwood BS (2015) Assessment of managed aquifer recharge site suitability using a GIS and modeling. Groundwater 53:389-400. doi:10.1111/gwat.12213

Sagintayev Z (2010) Integrated approach for the assessment and development of groundwater resources in arid lands: Applications in the Quetta Valley, Pakistan. Dissertation, Western Michigan University.

Sagintayev Z, Sultan M, Khan SD, Khan SA, Mahmood K, Yan E, Milewski A, Chouinard K (2011) Identification of aquifer types and potential well locations using GIS and remote sensing technologies in the Pashin Lora Basin. Вестник КазНУ. Серия географическая 1:32.

Sagintayev Z, Sultan M, Khan SD, Khan SA, Mahmood K, Yan E, Milewski A, Marsala P (2012) A remote sensing contribution to hydrologic modelling in arid and inaccessible watersheds, Pishin Lora basin, Pakistan. Hydrological Processes 26:85-99. doi:10.1002/ hyp. 8114

Sallwey J, Bonilla Valverde JP, Vásquez López F, Junghanns R, Stefan C (2019) Suitability maps for managed aquifer recharge: a review of multi-criteria decision analysis studies. Environmental Reviews 27:138-150. doi:10.1139/er-2018-0069

Saraf AK, Choudhury PR (1998) Integrated remote sensing and GIS for groundwater exploration and identification of artificial recharge sites. International Journal of Remote Sensing 19:1825-1841. doi:10.1080/014311698215018
Shaban A, Khawlie M, Abdallah C (2006) Use of remote sensing and GIS to determine recharge potential zones: the case of Occidental Lebanon. Hydrogeology Journal 14:433-443. doi:10.1007/s10040005-0437-6

Shankar MR, Mohan G (2005) A GIS based hydrogeomorphic approach for identification of site-specific artificial-recharge techniques in the Deccan Volcanic Province. Journal of Earth System Science 114:505-514. doi:10.1007/BF02702026

Singh A, Panda SN, Kumar KS, Sharma CS (2013) Artificial groundwater recharge zones mapping using remote sensing and GIS: a case study in Indian Pun-jab. Environmental Management 52:61-71. doi:10.1007/s00267-013-0101-1

Shubo T, Fernandes L, Montenegro SG (2020) An overview of managed aquifer recharge in Brazil. Water 12:1072. doi:10.3390/w12041072

Sophocleous M (2000) From safe yield to sustainable development of water resources-the Kansas experience. Journal of Hydrology 235:27-43. doi:10.1016/S0022-1694(00)00263-8

Steinel A, Schelkes K, Subah A, Himmelsbach T (2016) Spatial multicriteria analysis for selecting potential sites for aquifer recharge via harvesting and infiltration of surface runoff in north Jordan. Hydrogeology Journal 24:1753-1774. doi:10.1007/s10040-0161427-6

Taj MK, Liang Z, Zafar U (2018) CPEC Impact on Baluchistan Economy. International Journal of Research and Innovation in Social Science 2:69-70.

Todd DK, Mays LW (2004) Groundwater Hydrology. John Wiley \& Sons.

Umar M, Waseem A, Kassi AM, Farooq M, Sabir MA, Faridullah (2014) Surface and subsurface water quality assessment in semiarid region: A case study from Quetta and Sorange Intermontane Valleys, Pakistan. Global Nest Journal 16:938-954.

USGS Earth Explorer (2021) Online search, browse display, metadata export, and data download platform for earth science data from the archives of the U.S. Geological Survey. Available from: https:/ earthexplorer.usgs.gov/ - last accessed 25/01/2021

Van der Gun J (2012) Groundwater and Global Change: Trends, Opportunities and Challenges. WWDR4 Side Publication Series No 01, UNESCO, Paris. 